\title{
Optimasi Pesawat Atwood Menggunakan Sensor LDR (Light Dependent Resistor)
}

\author{
Adlian Jefiza $^{1^{\star}}$, Hafidz Novianas ${ }^{2}$ \\ ${ }^{1}$ Politeknik Negeri Batam, Jurusan Teknik Elektro, Batam \\ ${ }^{2}$ Universitas Muhammadiyah Riau, Jurusan Fisika, Pekanbaru \\ *E-mail: adlianjefiza@polibatam.ac.id
}

\begin{abstract}
Abstrak
Pesawat Atwood merupakan alat yang sering digunakan untuk membuktikan hukum-hukum tentang gerak. Di Laboratorium Fisika Universitas Muhammadiyah Riau, pengukuran pada pesawat Atwood masih dilakukan secara manual dengan menggunakan stopwatch. Penggunaan stopwatch untuk menghitung waktu dianggap tidak optimal karena butuh ketelitian yang akurat yang terkadang mendapatkan hasil yang tidak presisi dan akurat. Pada penelitian ini dirancang sebuah alat yang dapat mengukur percepatan secara otomatis pada pesawat Atwood menggunakan sensor LDR. Alat ini digunakan untuk mengukur percepatan beban jatuh pada jarak 25, 35 dan $40 \mathrm{~cm}$ dengan massa beban tambahan 10, 15, dan 20 gram. Dari hasil pengukuran percepatan secara otomatis diperoleh persentase kesalahan rata-rata 3,97\%. Hal ini menunjukan bahwa pengukuran percepatan pada pesawat Atwood secara otomatis menggunakan sensor LDR memiliki tingkat keberhasilan $96,03 \%$ dibandingkan dengan pengukuran percepatan yang dilakukan secara manual yang hanya memiliki tingkat keberhasilan $89,82 \%$.
\end{abstract}

Kata kunci: Percepatan, Pesawat Atwood, Sensor LDR

\begin{abstract}
Atwood machines are tools that are often used to prove motion theory. At the Physics Laboratory, University of Muhammadiyah Riau, measurements at the Atwood machine still use manual methods using a stopwatch. The use of a stopwatch to calculate time is considered not optimal because it requires high accuracy which sometimes gets results that are not precise and accurate. In this study, a device that is capable of automatically measuring acceleration on an Atwood engine using an LDR sensor is designed. This device is used to measure the acceleration of loads falling at a distance of 25, 35 and $40 \mathrm{~cm}$ with an additional mass of 10, 15 and 20 grams. From the results of automatic acceleration measurements, the average error percentage is $3.97 \%$. This shows that the acceleration measurement on Atwood machines automatically using the LDR sensor has a success rate of $96.03 \%$ compared to the acceleration measurements done manually which only have a success rate of $89.82 \%$.
\end{abstract}

Keywords: Acceleration, Atwood machines, LDR sensor 


\section{Pendahuluan}

Fisika adalah ilmu yang mempelajari tentang fisis, komposisi perubahan energy [1]. Perkembangan teknologi sekarang ini memiliki konsep dasar Fisika. Konsep dasar fisika dapat diterapkan dalam pengembangan ilmu lainnya, seperti otomotif, kedokteran, penerbangan, dan lainnya.

Dalam praktikum dasar fisika, banyak alat peraga yang dapat membuktikan konsep dasar fisika. Misalkan kincir angin yang digunakan untuk membuktikan energy gerak, ataupun pesawat hidrolik yang menjelaskan konsep Hukum Pascal, begitu juga dengan bejana kapiler atau yang biasa disebut bejana berhubungan yang menjelaskan tekanan dari zat cair yang berbeda massa, dan masih banyak lainnya.

Pesawat Atwood merupakan salah satu alat percobaan fisika untuk penerapan hukumhukum Newton. Alat tersebut terdiri dari 2 beban yang dihubungkan dengan tali melalui sebuah katrol dengan massa katrol dan tali diabaikan. Pesawat Atwood dapat menentukan nilai kecepatan, percepatan, dan momen inersia dari suatu benda. Nilai kecepatan diperoleh dari percobaan mengenai gerak lurus beraturan, sedangkan nilai percepatan diperoleh dari nilai gerak lurus berubah beraturan. Untuk mendapatkan nilai kecepatan dan percepatan, dapat diukur berdasarkan waktu pergerakan benda dari suatu titik ke titik yang lain. Biasanya dalam praktikum fisika dasar, untuk mendapatkan waktu pada pesawat Atwood menggunakan stopwatch. Penggunaan stopwatch digunakan untuk mengukur waktu disaat benda bergerak dari satu titik ke titik yang lain, sehingga diperoleh kecepatan dan percepatan benda pada pesawat Atwood. Untuk tampilan pesawat Atwood dapat dilihat pada Gambar 1. Gambar 1 merupakan contoh dari pesawat Atwood yang digunakan di Laboratorium. Pesawat Atwood digunakan untuk praktikum fisika dalam pengukuran kecepatan dan percepatan momentum. Untuk pengukuran waktu, penggunaan alat peraga pesawat Atwood ini masih menggunakan stopwatch.

Dalam pengukuran kecepatan, percepatan dan momentum pada pesawat Atwood harus mendapatkan hasil yang presisi dan akurat. Namun penggunaan stopwatch dalam perhitungan waktu masih belum maksimal. Ada beberapa faktor yang mengakibatkan pengukuran waktu kecepatan, percepatan, dan momentum pada pesawat Atwood. Penyebab ketidakpresisin dan akurasi hasil pengukuran dapat disebabkan oleh penggunaan stopwatch yang tidak stabil. Ketepatan penggunaan stopwatch ini dipengaruhi oleh ketelitian pengguna. Momen disaat benda jatuh dan penggunaan stopwatch harus bersamaan. Oleh karena itu, penggunaan stopwatch untuk mendapatkan hasil pengukuran yang presisi dan akurat masih belum maksimal. Maka diharapkan adanya pembaharuan pada pesawat Atwood sehingga mendapatkan hasil yang lebih baik.

Mengatasi kurang telitinya pengambilan data pada pesawat Atwood tersebut salah satu alternatifnya yaitu dengan merancang sistem otomatisasi pesawat Atwood menggunakan mikrokontroler. Perancangan sistem otomatisasi pada pesawat Atwood pernah dilakukan oleh Dema Siska Afrilla dengan menggunakan sensor getar. Hasil dari penelitian yang dilakukan diperoleh persentase kesalahan berkisar antara $1,95 \%-4,34 \%$, dan disarankan untuk melakukan pengembangan dalam hal tampilan data serta ditambahkan suatu rangkaian eksternal untuk menghubungkan bangun rangkaian otomatis ini kepada komputer dan pemograman yang mendukung [2].

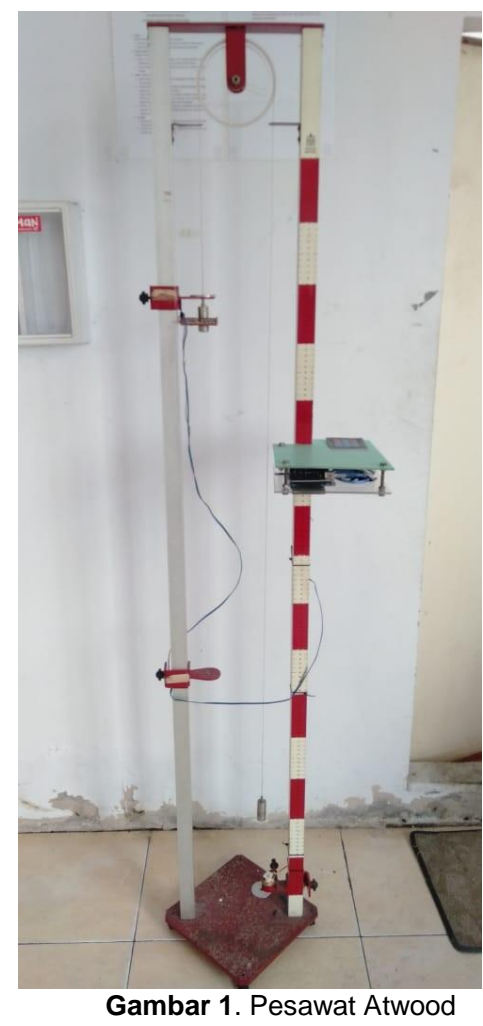

Penelitian yang relevan juga dilakukan oleh Fitri Yani. Penelitian yang dilakukan dengan menambahkan sensor Ultrasonik sebagai pendeteksi beban yang jatuh pada pesawat Atwood. Dari hasil pengukuran waktu secara 
otomatis diperoleh persentase kesalahan untuk perhitungan kecepatan $0 \%$, sedangkan untuk percepatan diperoleh persentase kesalahan $0,39 \%$ saat penambahan beban 29,2 gram namun untuk penambahan yang massanya kecil menghasilkan kesalahan 6,1 - 6,62\% [3].

Berdasarkan permasalahan dan hasil penelitain sebelumnya, maka diperlukan pembaharuan pesawat Atwood dengan memaksimalkan sistem otomatisasi. Pada penelitian kali ini dirancang suatu sistem otomatisasi waktu menggunakan sensor LDR dengan tambahan tampilan pada LCD dan panel keypad untuk pengaturannya

\section{Metode Penelitian}

Penelitian ini dilaksanakan di labor Fisika Universitas Muhammadiyah Riau. Adapun tahapan penelitian dapat dilihat di Gambar

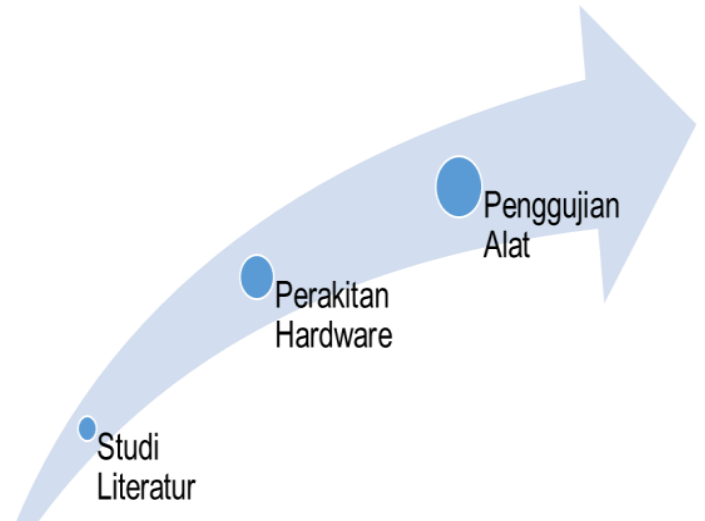

Gambar 2. Alur Penelitian

\section{A. Studi Literatur}

Pengambilan landasan studi dalam penelitian ini berdasarkan jurnal dan buku panduan. Jurnal yang digunakan berkaitan dengan otomasi pesawat Atwood.

\section{B. Perakitan Hardware}

Alat-alat yang dibuktuhkan dalam perakitan otomatisasi pesawat Atwood diantaranya laser diode, mikrokontroler jenis Ardiono Nano, sensor LDR, keypad, dan LCD 16x2.

\section{Laser Dioda}

Laser diode atau yang biasa disebut dioda laser merupakan komponen semikonduktor yang dapat menghasilkan radiasi Koheren dalam bentuk spectrum infra-red ketika dialiri listrik. Laser diode ini digunakan dipantulkan pada LDR.
Jika ada beban yang jatuh mengenai sinar laser yang dihasilkan laser dioda menimbulkan perubahan nilai tahanan pada sensor LDR.

\section{Arduino Nano}

Arduino Nano digunakan sebagai kontroler dari LCD, LDR, dan keypad.

\section{Keypad}

Keypad berfungsi memberikan perintah dimulai menjalankan program sehingga waktu pengukuran lebih akurat dan presisi

\section{Sensor LDR}

Sensor LDR berfungsi sebagai penangkap cahaya yang dihasilkan oleh laser diode. Perubahan nilai tahanan pada LDR berfungsi sebagai indikator apakah beban melewati sensor sehingga dapat diketahui berapa waktu jatuh beban [4].

\section{LCD 16x2}

LCD digunakan sebagai tampilan waktu jatuh benda, nilai kecepatan, dan nilai percepatan.

Dalam perakitan hardware, prinsip kerja dari Laser diode akan memancarkan cahaya yang ditangkap oleh sensor LDR. Jika cahaya dari laser diode masih $>150$, ini mengindikasikan bahwa belum ada benda yang jatuh melewati Laser Dioda. Jika nilai LDR <150, maka mengindikasikan bahwa ada benda yang melewati laser diode. Sensor LDR digunakan akan mendeteksi beban sekaligus untuk menghidupkan dan mematikan timer. Waktu tersebut akan tercatat mulai dari waktu awal jatuh benda, sehingga disaaat benda jatuh melewati sensor LDR, timer secara otomatis akan berhenti. Dari waktu dan data yang diperoleh, dapat diketahui nilai percepatan dengan menggunakan rumus :

$$
a=\frac{2 x m}{s^{2}}
$$

Informasi waktu dan percepatan akan ditampilkan pada layat LCD yang dipasang di badan pesawat. Semua perangkat ini dikontrol oleh Arduino tipe Uno. Untuk lebih detainya dapat dilihat pada Gambar 3 


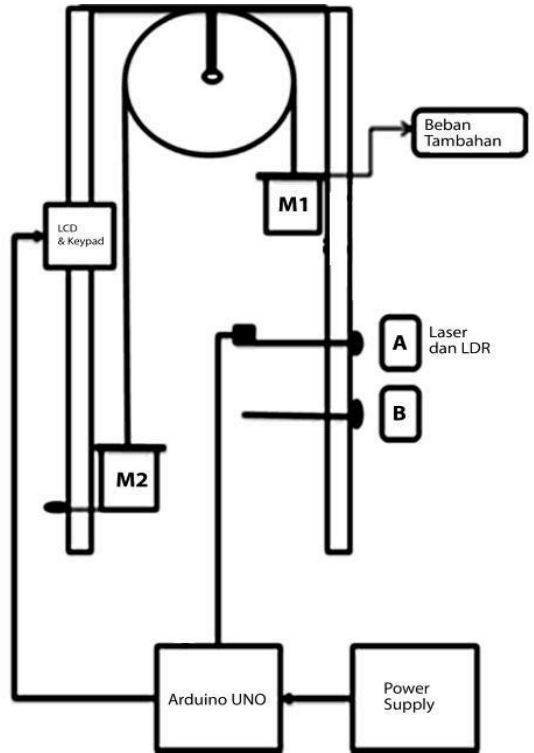

Gambar 3. Skema rancangan otomatisasi pesawat Atwood

Gambar 3 menjelaskan perangkat optimasi otomatisasi pesawat Atwood. Apabila beban dari $\mathrm{m} 1$ meluncur jatuh melewati laser dan Idr, maka informasi akan disampaikan dan ditampilkan pada LCD.

\section{Pengujian Alat}

Pengujian perangkat dilakukan untuk apakah pesawat Atwood dapa mendeteksi beban dengan benar sehingga dapat mengetahui percepatan benda. Setelah pengujian selesai, dilakukan tahap pengukuran percepatan pada pesawat Atwood. Pengukuran dilakukan pada jarak 25,35 , dan $40 \mathrm{~cm}$ dengan beban tambahan 10, 15, 20 gr. Setiap nilai waktu dan nilai percepatan yang dihasilkan disetiap jarak dan beban yang berbeda, dicatat dan dibandingkan dengan nilai percepatan yang diperoleh dengan menggunakan rumus manual (secara teoritis) :

$$
A=\left(m+m_{1}\right)-m_{2} \cdot g
$$

Pengujian dilakukan dengan mengambil data waktu secara otomatis, dimana variasi jarak dan beban tambahan sama dengan yang dilakukan pada pengambilan data waktu secara manual. Untuk mencari percepatan maka sensor akan dipasang pada posisi A. Awalnya beban diam dan tidak bergerak karena ditahan oleh efek magnetis oleh kumparan yang dialiri arus listrik. Ketika tombol mulai ditekan, mikrokontroler akan memberikan trigger untuk memutuskan arus listrik kumparan, sehingga efek magnetis hilang dan beban terlepas dan bergerak. Ketika beban terlepas, mikrokontroller mencatat waktu mulai. Ketika beban mencapai titik A dan menutup cahaya laser yang menembak LDR, maka terjadi penurunan drastis tegangan sensor LDR. Mikrokontroller menanggapinya dengan mencatat waktu akhir. Kemudian mikrokontroller akan melakukan perhitungan dengan mengurangkan waktu akhir dengan waktu awal, sehingga mendapatkan waktu tempuh beban. Terakhir mikrokontroller akan melakukan perhitungan untuk mencari nilai percepatan, hasil pegukuran waktu dan percepatan diteruskan untuk ditampilkan ke LCD.

Pengukuran kedua dilakukan menggunakan stopwatch. Penggunaan stopwatch dilakukan untuk melihat perbandingan hasil pengukuran menggunakan perangkat otomatisasi, nilai hasil teoritis dan nilai percepatan menggunakan stopwatch.

\section{Hasil dan Diskusi}

Hasil dari penelitian ini adalah sebuah prototype alat otomatisasi waktu pada alat ukur Pesawat Atwood berbasis mikrokontroler Arduino Uno Untuk bentuk hasil optimasi otomatisasi pesawat Atwood dapat dilihat pada Gambar 4.

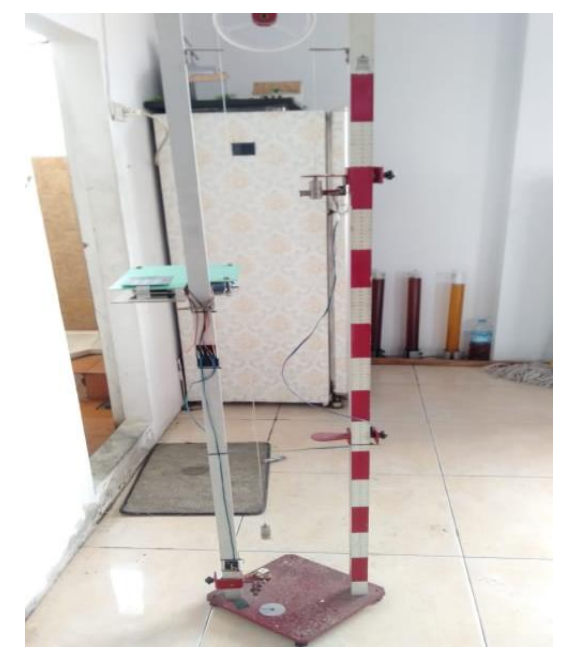

Gambar 4. Pesawat Atwood Otomatis

Gambar 4 merupakan bentuk keseluruhan dari pesawat Atwood yang sudah dilengkapi dengan sensor LDR, LCD, keypad dan laser diode. Lebih jelas dapat dilihat pada Gambar 5 dan 6 


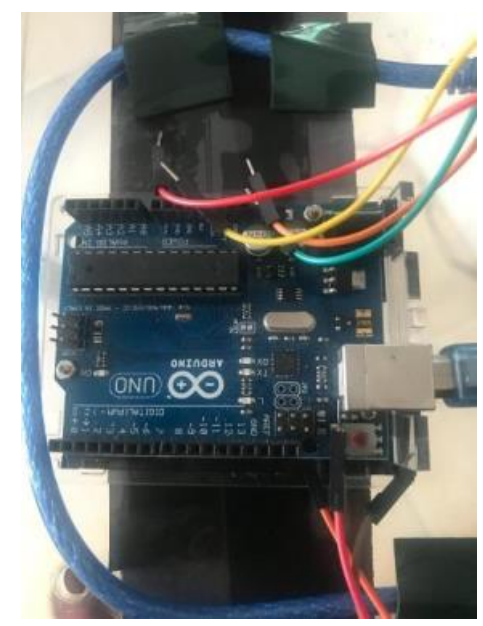

Gambar 5. Mikrokontroler pada Pesawat Atwood

Gambar 5 merupakan mikrokontroler yang digunakan sebagai control sensor untuk otomatisasi Pesawat Atwood. Mikrokontroler dipasangkan pada tiang pesawat Atwood agar dapat membaca data sensor dengan presisi. Untuk menampikan data kecepatan atau hasil pengukuran pada pesawat Atwood, nilai percepatan akan di tampilkan layar LCD yang terpasang di tiangnya. Adapun bentuk dari LCD nya dapat dilihat pada gambar 6 .

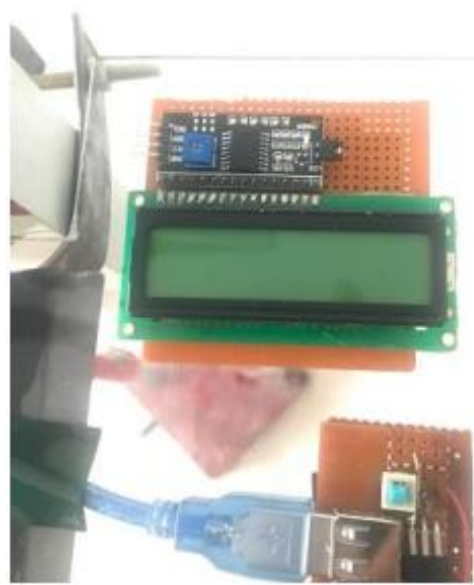

Gambar 6. Tampilan LCD Otomatisasi Pesawat Atwood

Setelah perangkat selesai, dilakukan pengujian pesawat Atwood. Untuk pengujian pertama, dilakukan pengujian waktu jatuh benda pada pesawat Atwood. Hasil pengujian dapat dilihat pada Tabel 1.
Tabel 1. Pengujian Pesawat Atwood pada Efisiensi Waktu

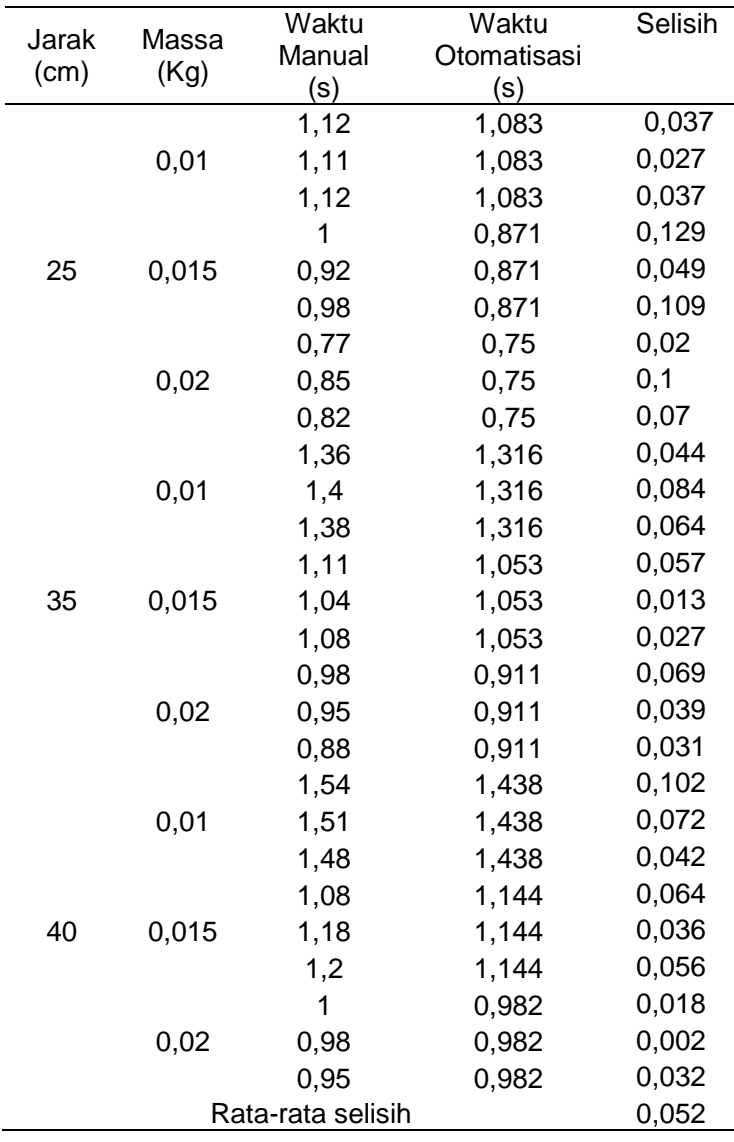

Tabel 1 merupakan pengujian pesawat Atwood berdasarakan efisiensi waktu berdasarkan jarak dan massa benda. Untuk jarak dibagi atas 3, yaitu $25 \mathrm{~cm}, 35 \mathrm{~cm}$ dan $40 \mathrm{~cm}$. Sedangkan pengujian massa benda menggunakan tiga jenis massa benda tiap jarak yang berbeda. Tiap-tiap jarak, pengujian massa benda menggunakan 0,01 Kg, 0,015 $\mathrm{Kg}$ dan 0,02 Kg.

Pengujian dilakukan dalam dua tahapan, yaitu secara manual dan secara otomatis. adapun perbandingan atau selisih dari kedua pengujian tersebut adalah 0,052. Perbandingan waktu ini sangat kecil antara pengukutan manual dan otomatis.

Pengujian kedua dilakukan untuk melihat percepatan jatuh benda pada Pesawat Atwood. Pengujian dilakukan dengan jarak $25 \mathrm{~cm}, 35 \mathrm{~cm}$ dan $40 \mathrm{~cm}$ dengan tiap kali pengujian digunakan massa benda $10 \mathrm{~g}, 15 \mathrm{~g}$ dan $20 \mathrm{~g}$. hasil pengujian kedau dapat dilihat pada tabel 2 . 
Tabel 2. Pengujian Pesawat Atwood terhadap Percepatan

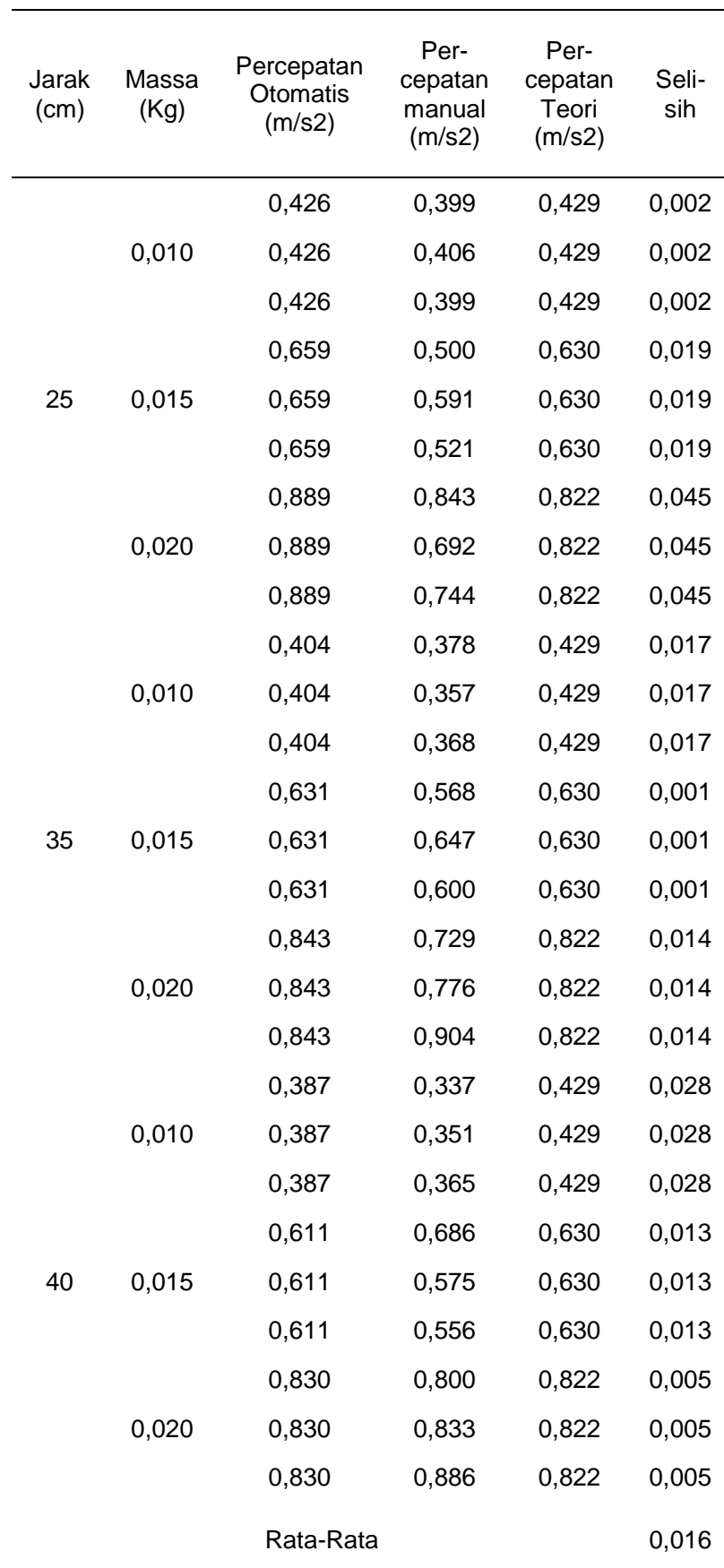

Pada Tabel 2 dijelaskan bahwa pengujian alat dilakukan menggunakan 3 jarak, $22 \mathrm{~cm}, 35$ $\mathrm{cm}$ dan $40 \mathrm{~cm}$. Beban yang digunakan adalah 10 gram, 15 gram dan 20 gram. Pengujian dilakukan dengan tiga tahapan yaitu menghitung percepatan secara otomatis, menghitung percepatan secara manual dan menghitung percepatan secara teori. Perhitungan percepatan secara teori menjadi acuan dalam melihat selisih dari setiap pengujian. Hasil dari perhitungan percepatan diperoleh rata-rata selisih nilai sebesar 0,016. Nilai selisih dianggap memiliki jarak selisih yang rendah.

Pengujian terakhir yaitu melihat persentase error dari setiap pengukuran yang telah dilakukan. Untuk melihat rata-rata error pada perhitungan percepatan dapat diamati pada Gambar 7.

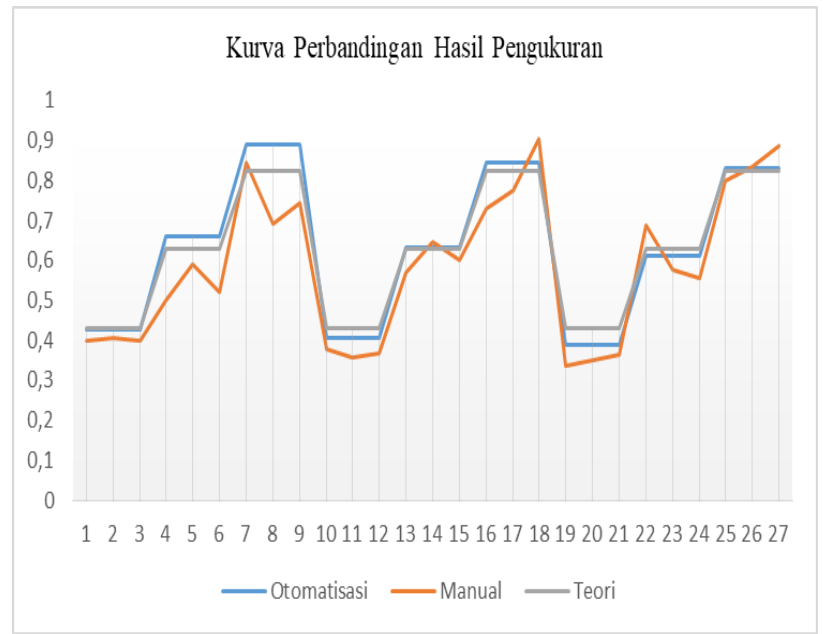

Gambar 7. Perbandingan Hasil Pengukuran Percepatan Pesawat Atwood

Berdasarkan Gambar 7, dapat diamati bahwa dari ketiga pengujian, nilai percepatan yang peroleh pada alat otomatisasi memperoleh hasil yang mendekati dengan nilai percepatan menggunakan rumus dengan persentase kesalahan sebesar 3,97\%. Sedangkan nilai percepatan menggunakan stopwatch menunjukkan nilai kesalahan yang cukup besar yaitu sekitar $10,18 \%$. Dengan hasil ini, dianggap rancang bangun optimasi otomatisasi pesawat Atwood berbasis sensor LDR memperoleh hasil yang lebih baik dibandingkan penelitian sebelumnya.

\section{Simpulan}

Setelah melakukan pengujian dan analisa terhadap alat otomatisasi pesawat Atwod, maka dapat disimpulkan bahwa perakitan sebuah alat otomatisasi pengukur waktu pada pesawat Atwood dengan menggunakan sensor LDR, mikrokontroler, dan LCD mendapatak hasil yang cukup baik.Dengan melakukan pengujian percepatan berdasarkan jarak $25,35,40 \mathrm{~cm}$ dan penambahan beban 10, 15, 20 gram menghasilkan persentase kesalahan dalam pengukuran waktu secara otomatis sebesar 
3,97\%, sementara dengan cara manual mencapai $10,18 \%$.

Untuk pengembangan otomatisasi pesawat Atwood, diharapkan untuk lebih meningkatkan akurasi dan dengan tampilan yang lebih baik

\section{Daftar Pustaka}

[1] Alat peraga pembelajaran dan praktikum fisika. [Online] Available: https://sites.google.com/site/soalundanvideo praktikum/[ Aug. 18, 2020).

[2] Dema Siska Afrilla, Walfed Tambunan, and Sugianto, "Rancang Bangun Rangkaian Timer Otomatis Pesawat Atwood," Jom Fmipa, vol. 1, pp. 1-6.

[3] Fitri Yani, Yeeri Badrun, and Sri Fitria Retnowati, "Otomatisasi Waktu Pada Pesawat Atwood Menggunakan Sensor HcSr04," in 1th Celscitech-UMRI, 2016, pp. 7376.

[4] Ahmad Solihun, Arif Maftukhin, and Eko Setyadi Kurniawan, "Pengembangan Alat Peraga GLB dan GLBB Berbasis Sensor LDR (Light Dependent Resistor)," J. Radiasi, vol.06, pp. 110-114.

[5] Firman Nugraha, Resti Wulansari, and Kartika Hajar Kirana, "Eksperimen Pesawat Atwood Berbasis Pengolahan Aplikasi Tracker Untuk Mengamati Fenomena Gerak Lurus Beraturan Dan Gerak Lurus Berubah Beraturan Pada Pembelajaran Fisika Sma," Pros. Semin. Nas. Fis. E-J. SNF, 2017, vol. VI. 